\title{
DIDACTIC ALGORITHM IN DESIGNING MULTIMEDIA EDUCATIONAL PROGRAMMES
}

\section{Waldemar LIB}

\begin{abstract}
The article presents the issues connected with designing multimedia didactic programmes. During the designing stage, there are decisions taken on the structure of a didactic programme, the way of presenting its educational contents, their methodological layout as well as the adjustment of media needed to pass and check newly acquired knowledge. In most cases, the creation of the structure of a multimedia didactic programme and application of specific media relies on the selection of information technologies that allow for its implementation.
\end{abstract}

Key words: designing didactic multimedia programmes, algorithm, didactic algorithm.

\section{ALGORYTM DYDAKTYCZNY W PROJEKTOWANIU MULTIMEDIALNYCH PROGRAMÓW DYDAKTYCZNYCH}

Streszczenie: $W$ artykule poruszana jest problematyka zwiazana z projektowaniem multimedialnych programów dydaktycznych. To na etapie projektowania podejmowane sa decyzje, dotyczące struktury programu dydaktycznego sposobu prezentowania treści ksztalcenia, ich uktadu metodycznego, doboru mediów stużących do przekazywania i sprawdzania nowo nabytych wiadomości. Często konsekwencja ustalenia struktury multimedialnego programu dydaktycznego i zastosowania określonych mediów jest wybór technologii informatycznych stużących do jego realizacji.

Stowa kluczowe: projektowanie multimedialnych programów dydaktycznych, algorytm, algorytm dydaktyczny.

The process connected with designing and performing multimedia didactic programs consists of certain phases, within the scope of which there are certain activities and their pace leads to final performance of a computer program needed for educational applications.

Designing and performing of a didactic programme may be divided into five phases dependent on one another (Lib 2006: 81).

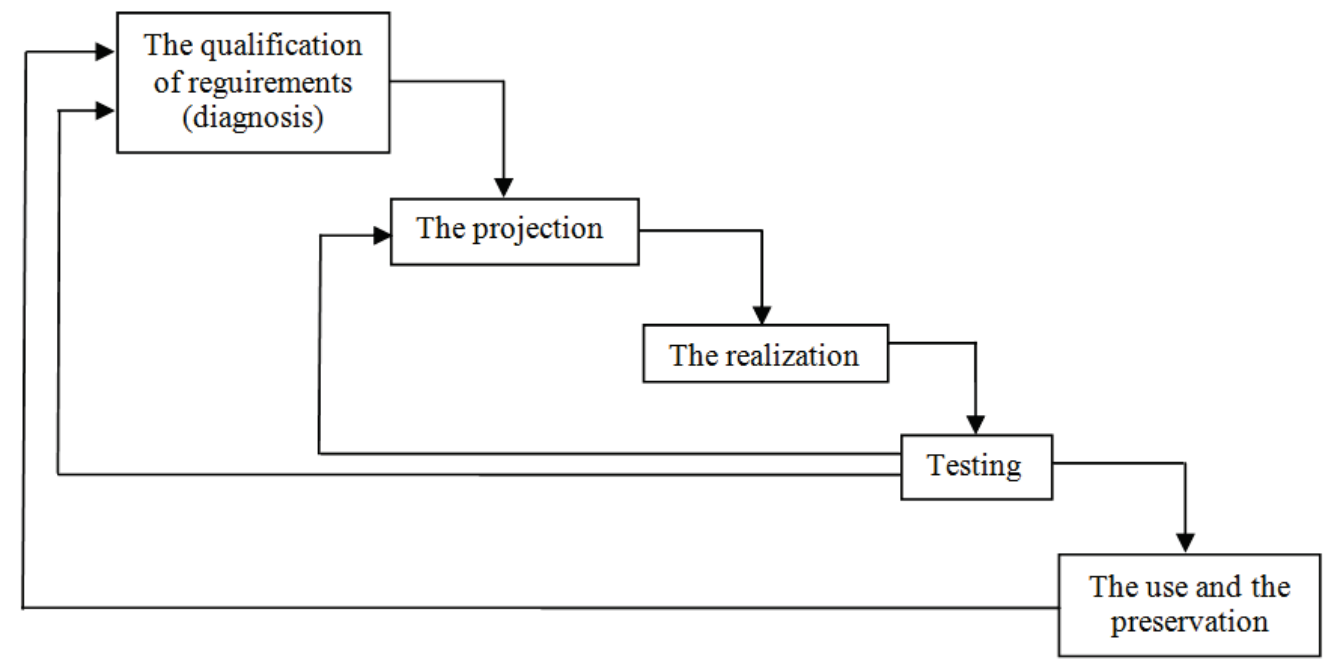

Fig. 1. Diagram of five phases of designing and performing a multimedia didactic programme Source: Lib 2006: 82 
The most important phase, apart from diagnosis, in which there are performed, i.a. analyses, for whom the program is assigned (definition of a receiver and educational level, on which it will be used), how it will be used (during school lessons, extra-school activities or by pupils at home) etc. is undoubtedly designing. Designing is the most significant phase connected with performing a multimedia didactic programme. The layout of education contents is finally prevailing within a program, how they will be presented to a learner, what media will be used and how it will be launched by a user. In the phase of designing there is a decision made what IT will be used by a creator that designs a program. It directly influences the quality and way of the program, but it also has a possibility of launching it by computer users. The choice of IT may be prevailing whether the performed program will be working on all computers regardless of their hardware or whether it will be working on computers with great calculating power and equipped with e.g. graphical cards of great capacity, RAM of great capacity, fast processors or on the computers which have the newest operating systems installed such as Windows Vista or Windows.

The result of designing is to develop the algorithm of a computer program. In IT, an algorithm is understood as the sequence of clearly and precisely defined activities needed to perform and implement certain tasks. An algorithm may be implemented in form of a computer program or for any other device e.g. $\mathrm{CNC}$ working machines, a device keeping a constant temperature within a room etc. The mistakes made during developing an algorithm may have various or even serious consequences, they may decide on the lack of effectiveness or total fiasco of undertaken actions. A mistakenly developed algorithm of a multimedia didactic program e.g. due to factual reasons, inappropriate sequence of presented portions of knowledge, wrong connection of an information part of a program in which there is presented new education content for a pupil, e.g. with a checking block, may lead to a cognitive dissonance. Instead of ordering and applying newly acquired information, there is their muddying, mixing and reluctance of learners against the presented content.

In order to present or pass an assumed sequence of action to another user, an algorithm has to be written down on a piece of paper or other carrier. A natural language may be used, especially the one which has been used by a human being to save various "simple" regulations and rules e.g. recipes for hundreds of years. However, the emergence of machines and computers, for which it was necessary to save more and more complicated or even long sequences of conduct, calculation, analysis and presentation, for which the verbal saving of an algorithm was too time consuming and did not guarantee a precise understanding of a receiver, what the author of this algorithm had in mind, forced to create new forms of its saving. At present, the best way of recording and presenting algorithms is a block diagram. Defined by IT specialists block diagrams of algorithms are created from certain blocks connected with each other by means of arrows.

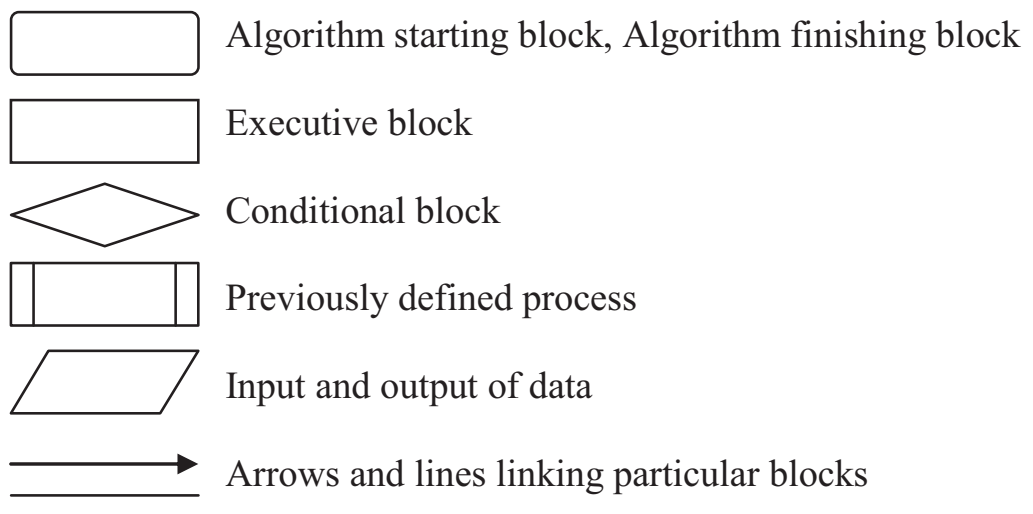

Use of the aforementioned elements allows for developing the following algorithm. 


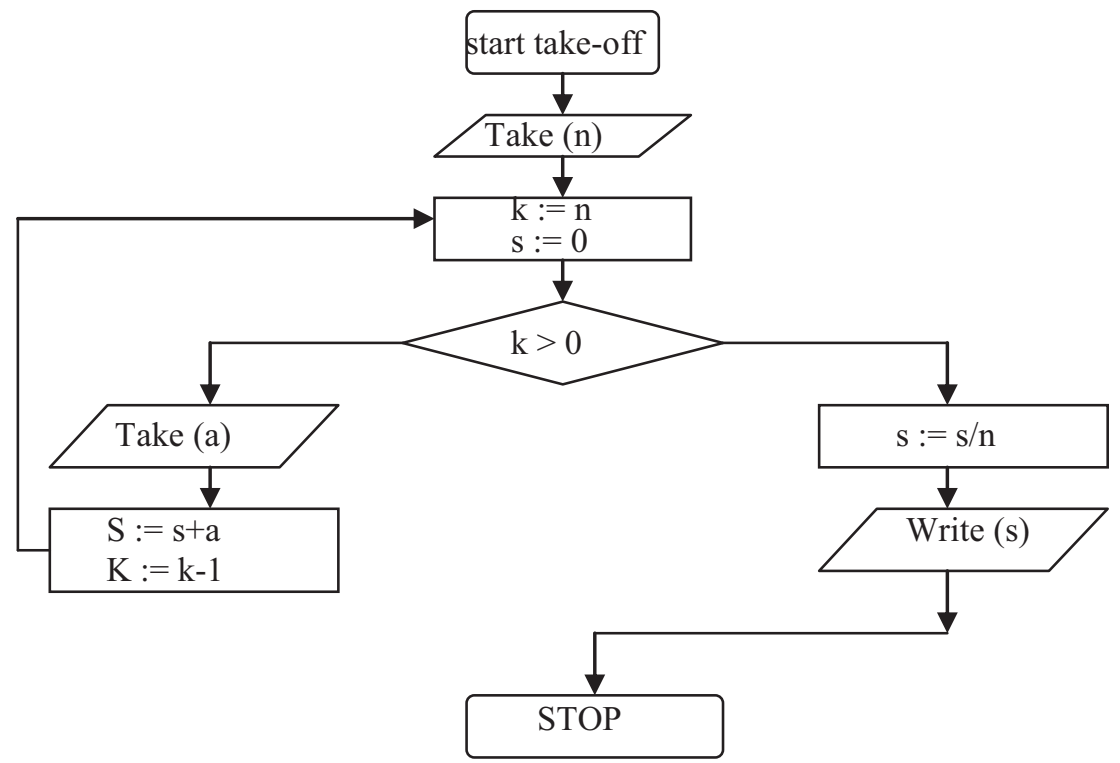

Fig. 2. Block diagram of a algorithm needed for calculating an arithmetic average from the given number of digits by a user. Source: Internet 1.

Such presentation of an algorithm, sufficient for the application in information technology, in the event of teachers' designing of multimedia didactic programmes does not pass full information on the program. It informs about the way of introducing data, their processing, conducted calculations and other aspects connected with performed actions, but it does not state e.g. the number of screens (slides) included in the program, factual contents of a program and a methodological manner of organising (connecting) particular content included in the program.

It seems that a better solution during designing multimedia didactic programs is to develop an algorithm of a didactic program in form that its saving clearly presented:

full contents of a

program, i.e. the number of displayed individual screens,

$\begin{array}{cc}- & \text { program blocks, e.g. } \\ \text { information blocks } & \text { constituting checking }\end{array}$

sections and blocks in form of partial tests or tasks to be performed at the end of sections or as an individual information block and independent on a checking block and totally amounting and assessing the level of acquiring knowledge by learners, included in the content of the program,

- technical manner of their connection with each other by means of hyperlinks,

- factual content of a designed didactic program,

- used media,

- methodological manner of connecting particular information with each other.

This way of a graphical saving of the designed multimedia didactic program presenting the way of action of a program is referred to as a didactic algorithm. 


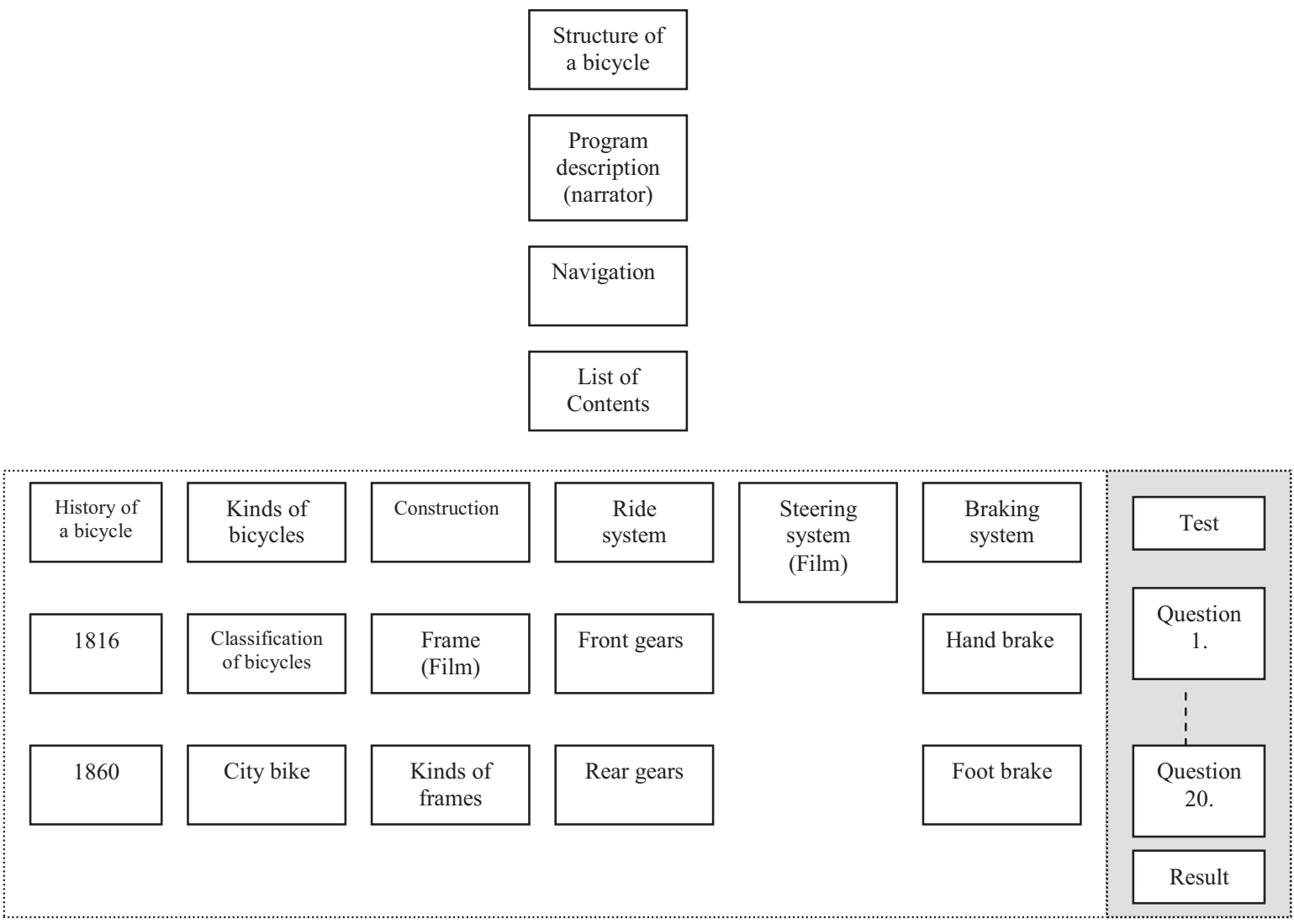

Fig. 3. Fragment of a didactic algorithm of a multimedia didactic program assigned for pupils of 4th grade of primary school for the lessons in the scope of Transportation Education Structure of a bicycle. Source: own study

Hand brake

This block means one slide - one screen displayed on a computer screen. The title inside the block means the title of a displayed screen, and this means contents which will be displayed on it.

Fig. 3. presents a fragment of a didactic algorithm of a program assigned for the lessons on Transportation Education regarding the structure and equipment of a bicycle. At this stage, we will be concluding how many slides (screens) are included in the program, what main blocks will constitute its basis. The program will consist of two main blocks - information block, including factual contents which should be acquired by a learner in the course of working with a program and with a testing block, checking the level of acquiring the presented contents in the information block. At this moment, the designer defines the factual contents, which will be included in the program and the means of expression apart from text and graphics e.g. film, narrator.

Another stage is to define hypertext links between the factual content presented on the subsequent screens.
Fig. 4. presents the same, as on fig. 3., fragment of a didactic algorithm, though, be means of lines there are connected certain screens which are, according to a designer of a multimedia didactic programme, connected among one another thematically, constituting a given closed portion of information on a given subject. At this stage, there is only to define the methodological part of the presented content, i.e. the manner of transferring between particular screens presenting particular portions of information. If, after entering a given section, there will be a possibility to e.g. return to the first screen of a new section to the list of contents or whether the learner will have certain limitations after having entering the section and will be obliged to go through the whole section and get familiar with new content. May be the return from the first slide of a new section will be justified at the moment when the link connecting 


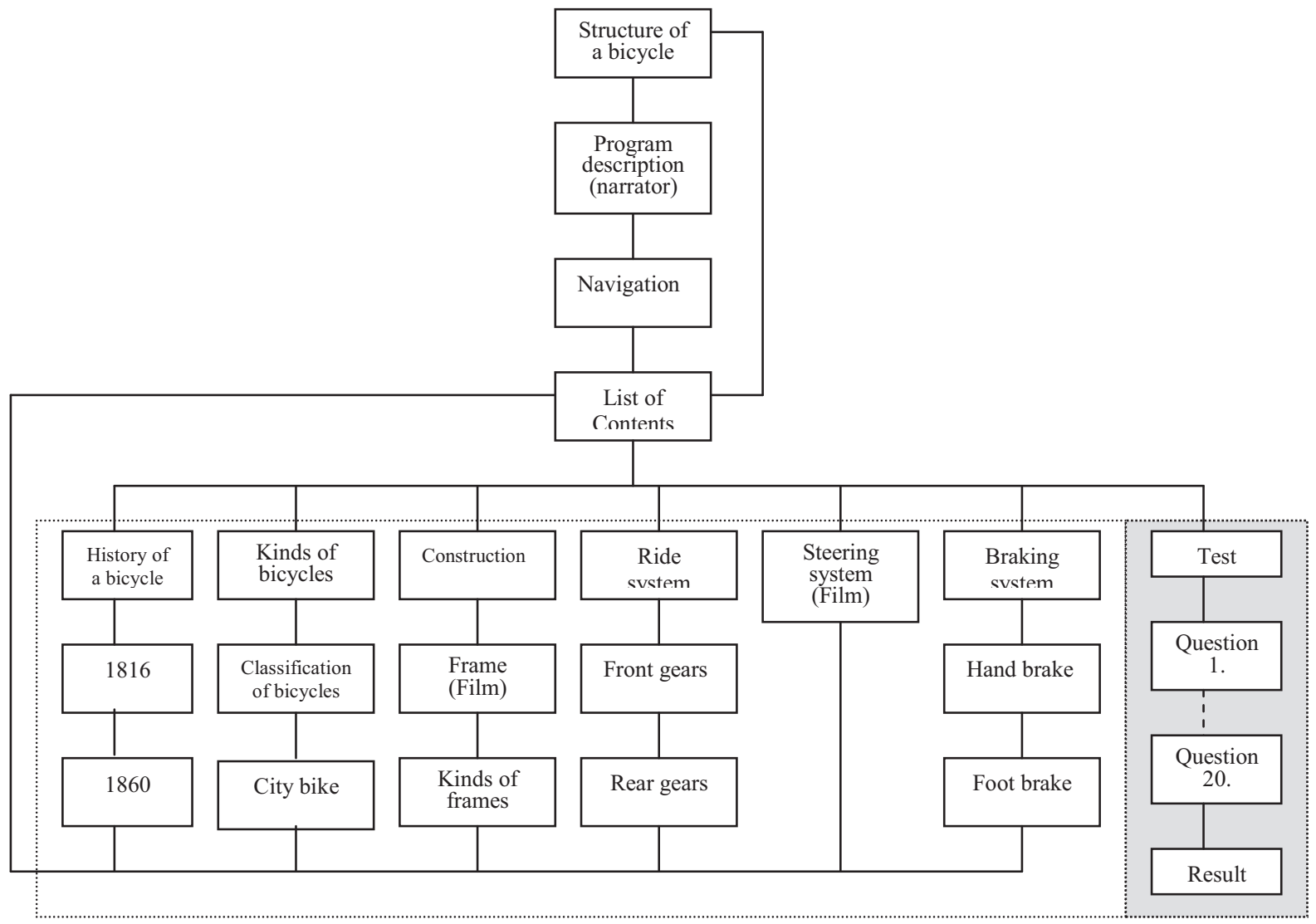

Fig. 4. Fragment of a didactic algorithm with assigned hypertext links between particular screens. Source: own study

the list of contents with a given section will be accidently launched by the user, and the return to the list of contents will require passing through several screens presenting the content already known to a learner, till the last one from which will be the return to the list of contents. Whether inside the sections, the learner will have an opportunity to unlimited transition forward and backward or will be able just to display a given screen and the next entering will be possible after displaying all screens and another entering will be possible only from the level of the list of contents. Obviously, all of these questions and doubts shall be answered by a teacher designing a given didactic program and they will be dependent upon the subject, aims of the program and its use (whether it is used at school or at home) and the level of the difficulty of the presented content etc.

Fig. 5. presents the methodological way of connecting the displayed content with each other on subsequent screens of multimedia didactic program allowing for multiple returns and single transitions through particular content portions. Arrow heads directs the transition towards subsequent slides, doubled direction arrows means the possibility of transition to the next slide or return to the previous slide.

\section{Conclusion}

Multimedia education programmes based on hypertext relies on a new group of didactic studies connecting messages prepared on the basis of various means of passing information. They constitute a homogenous didactic message and its application relies on a interactive character (both with reference to the teacher's activities and learner's) (Sieminiecki 1999: 131). They fulfil several functions, grouped in blocks, confirming their great significance as effective didactic measures allowing for the enrichment of knowledge and skills of learners and supporting their comprehensive development of personality. The most significant functions of didactic programs can be included:

- didactic-educational functions;

- informing function,

- motivating function,

- exercising function (practical),

- self-educational function,

- educational function,

- culture creating functions; 


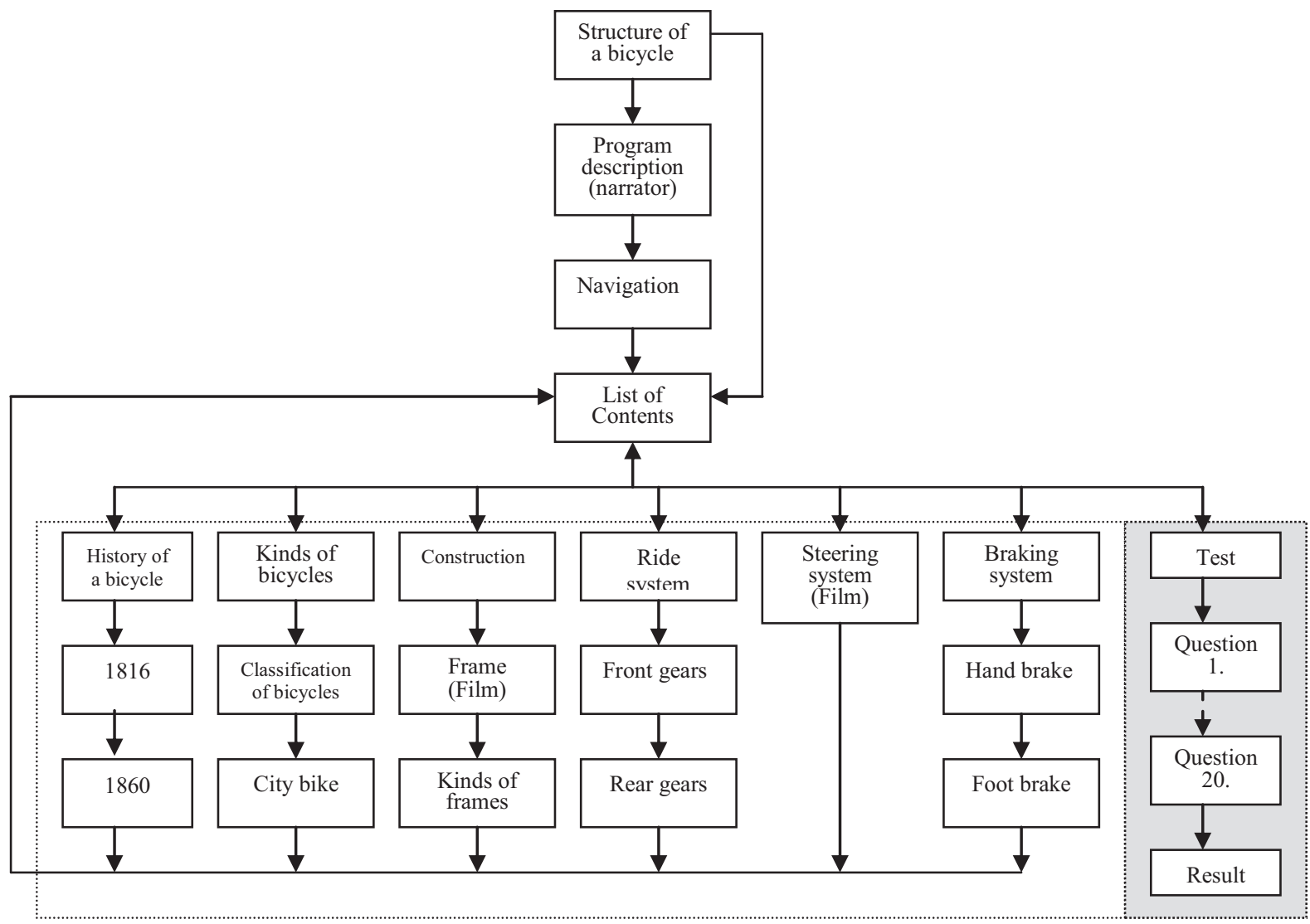

Fig .5. Fragment of a didactic algorithm with assigned hypertext links and directions between particular screens. Source: own study

- popularisation function,

- entertaining function,

- motivating function,

- modelling function,

- interpersonal function,

- general functions;

- cognitive-educating,

- emotional- motivating,

- activating - interactive (Walat 2008: 105-115).

Considering the aforementioned functions, which potentially may be fulfilled by a multimedia didactic programme within the process of education, in the course of its designing, it shall not be forgotten about any of the spheres which may be supported and developed in learners along with its support.

\section{Bibliography:}

[1] CHRÁSKOVÁ, M., CHRÁSKA, M., Postoje vysokoškolských studentů k osobnímu počítači v závislosti na vybraném studijním programu. 2010, [w:] Trendy ve vdělávání, red. M. Carska, Č. Serafin, M. Havelka Olomouc.

[2] DOSTÁL, J., Rozvoj ICT kompetencí pedagogických pracovníků [w:] Trendy ve vdělávání, red. M. Chraska, Č. Serafin, M. Havelka Olomouc.

[3] LIB, W., Multimedia w edukacji. „Edukacja ogólnotechniczna inaczej”. 2000, [Multimedia in education. Different all-technical education], no. 22.

[4] LIB, W., Methodology of the elaboration of multimedia didactic programmes. "Informatologia 2006".

[5] LIB, W., Walat W., 2007, Teacher's competences in modelling computer didactic programs. [w:] Competences and teacher competence, red. N. Babić, Osijek.

[6] OSMAŃSKA-FURMANEK, W., Furmanek M., 2006, Pedagogika mediów, [w:] Pedagogika - dyscypliny wiedzy pedagogicznej Tom 3, red. B. Sliwerski, Gdańskie Wydawnictwo Pedagogiczne, Gdańsk

[7] SERAFÍN, Č., Virtuálni stavebnice v technickém vdélávání. 2010, [w:] Trendy ve vdělávání, red. M. Carska, C. Serafin, M. Havelka Olomouc.

[8] SIEMIENIECKI, B., Komputery $i$ hipermedia w procesie edukacji dorostych, Pedagogika pedagogika wobec edukacji, polityki oświatowej i badań naukowych Tom 2. 1999, red. B. 
Śliwerski, Gdańskie Wydawnictwo

Pedagogiczne, Gdańsk.

[9] WALAT, W., Modelowanie podręczników techniki - informatyki. 2004, Wyd. U. R. Rzeszów.

[10] WALAT, W., Funkcje hipermedialnych programów dydaktycznych [w:] Technika Informatyka - Edukacja, Teoretyczne i praktyczne problemy edukacji informatycznej, 2008, red. W. Walat, Wyd. U. R., Rzeszów.

Internet:

http://gimrozy.neostrada.pl/informatyka/algorytm $\mathrm{y} / \mathrm{schemat} . \mathrm{html}, 20.04 .2010$

Dr Waldemar Lib

University of Rzeszow, Poland

Institute of Technology

Department of Didactics of Technology and Computer Science

16A, Rejtana Street

35-310 Rzeszow

E-mail: libw@univ.rzeszow.pl 